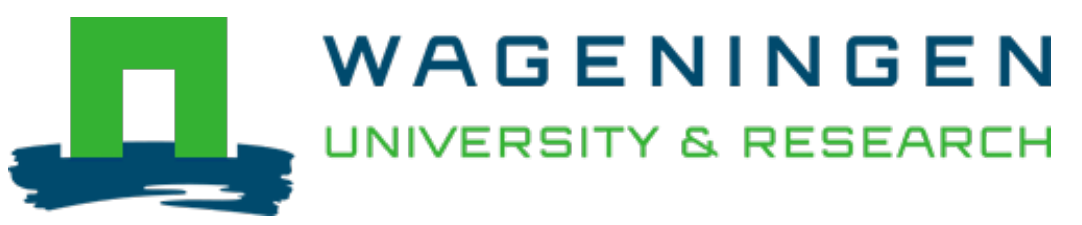

\title{
Implementation of purification equipment for removal of plant protection products from horticultural discharge water
}

\author{
Acta Horticulturae \\ Ruijven, J.P.M.; Os, E.A.; Staaij, M.; Eveleens-Clark, B.; Beerling, E.A.M. \\ https://doi.org/10.17660/ActaHortic.2020.1273.20
}

This publication is made publicly available in the institutional repository of Wageningen University and Research, under the terms of article $25 \mathrm{fa}$ of the Dutch Copyright Act, also known as the Amendment Taverne. This has been done with explicit consent by the author.

Article 25 fa states that the author of a short scientific work funded either wholly or partially by Dutch public funds is entitled to make that work publicly available for no consideration following a reasonable period of time after the work was first published, provided that clear reference is made to the source of the first publication of the work.

This publication is distributed under The Association of Universities in the Netherlands (VSNU) 'Article $25 \mathrm{fa}$ implementation' project. In this project research outputs of researchers employed by Dutch Universities that comply with the legal requirements of Article $25 \mathrm{fa}$ of the Dutch Copyright Act are distributed online and free of cost or other barriers in institutional repositories. Research outputs are distributed six months after their first online publication in the original published version and with proper attribution to the source of the original publication.

You are permitted to download and use the publication for personal purposes. All rights remain with the author(s) and / or copyright owner(s) of this work. Any use of the publication or parts of it other than authorised under article $25 \mathrm{fa}$ of the Dutch Copyright act is prohibited. Wageningen University \& Research and the author(s) of this publication shall not be held responsible or liable for any damages resulting from your (re)use of this publication.

For questions regarding the public availability of this publication please contact openscience.library@wur.nl 


\title{
Implementation of purification equipment for removal of plant protection products from horticultural discharge water
}

\author{
J.P.M. van Ruijven, E.A. van Os, M. van der Staaij, B. Eveleens-Clark and E.A.M. Beerling \\ Wageningen University \& Research, Business Unit Greenhouse Horticulture, Bleiswijk, The Netherlands.
}

\begin{abstract}
Surface waters in Dutch agricultural and horticultural areas do not meet the requirements of the European Water Framework Directive for good chemical and ecological water quality. Emission of nutrients and plant protection products (PPPs) from agricultural activity contributes to this. The Dutch government issued emission standards for nitrogen, evolving to zero discharge in 2027 for all greenhouse crops. However, to reduce the leaching of PPPs to surface and ground waters on the shortterm, additional legislation came into force January 1,2018 . This regulation obliges Dutch growers to use purification equipment for the removal of $95 \%$ plant protection products (PPPs) when discharging drain water to sewage or surface water. This stimulates growers to look critically at opportunities to reduce the amount of discharge water, thus lowering the investment and operational costs of purification equipment. In this article, we describe the implementation of the obligated purification for different types of cultivation systems, including the development of an approval protocol for purification equipment. Depending on the amount of discharged water and company size, growers will choose between either applying an installation at the company level or cleaning the water cooperatively with a group of locally located companies. Another option, especially suitable for infrequent small amounts of discharge water, is rental of a mobile purification unit. In any of these three cases, the growers must use an approved installation. The installation and the applied technical specifications (for example ozone dosage) need to be tested with so-called Standardised Water following a strict protocol. An installation is approved by a governmental committee if tested correctly with a purification efficacy of $95 \%$ for each of the 11 active ingredients of PPPs in Standardised Water.
\end{abstract}

Keywords: Standardised Water, surface water quality, greenhouse cultivation, environmental legislation, pesticides, zero-emission growing

\section{INTRODUCTION}

The European Water Framework Directive (WFD, 2000) aims to progressively reduce emissions of hazardous substances to waters, in order to achieve surface and ground waters of good chemical quality and ecological potential in all member states by no later than 2027 . Since the 1990s, reuse of nutrient solution is mandatory, but occasional discharges are allowed. Dutch regional water authorities monitor surface waters on concentrations of fertilisers and plant protection products (PPPs). The measurements on PPPs are published online and are visualized on a map, showing measured concentrations compared to surface water quality standards (CML, 2016). Several agricultural and horticultural areas can be clearly indicated on this map, by the large number of exceedances of these surface water quality standards. More detailed monitoring by the water authority of Delfland, including the Westland horticultural area (Hoogheemraadschap van Delfland, 2010, 2015, 2016, 2017), shows that chemical surface water quality is currently not yet sufficient and improvement is stagnating, in spite of the efforts in the horticultural sector made to close the water cycle. The main sources of pollution are from discharged drain and filter rinsing water (Beerling et al., 2014) but also leakage from the irrigation system (Groen, 2015), and leakage from soil-grown crops (less than $10 \%$ in the Netherlands) contribute significantly. 
To ultimately meet the WFD standards in 2027, Dutch government has issued new environmental legislation by 2013 (Activiteitenbesluit Milieubeheer, 2018). This legislation includes standards for emission of nitrogen (as nitrate and ammonium, $\mathrm{kg} \mathrm{N} \mathrm{ha}^{-1} \mathrm{y}^{-1}$ ) from greenhouses. Each crop has its own emission standards, decreasing every three years from 2013 onwards, leading to zero emission of nitrogen by 2027. An equal decrease in the emission of phosphorus and other nutritional elements is implicitly expected. Growers are obliged to keep record of the amount discharged and the concentration of nitrogen in the nutrient solution, and report it to the authorities. The goal of the nitrogen emission standards is to decrease the total amount of water discharged, thereby also eliminating the emission of phosphorus and PPPs to surface waters.

In the meantime, the registration policy for PPPs was changed in 2016, anticipating the EU-wide adoption of the Greenhouse Emission Model (GEM; Wipfler et al., 2015; Van der Linden, 2017). Instead of assuming an emission of active ingredients of $0.1 \%$ of the applied amount (Vermeulen et al., 2010), the actual emission was estimated by GEM. Elaborated validation of GEM is in progress. As calculated emissions of several active ingredients were much higher than $0.1 \%$ of the applied amount, re-admission of many highly relevant PPPs are at risk at re-evaluation. Therefore, to achieve both a good quality surface water (according to WFD) and preserving the (much needed) PPPs, the Dutch greenhouse sector and the government agreed on additional legislation to decrease PPP emissions: obligatory purification of discharged water. This legislation is in force since January 1,2018. This article describes the implementation of the obligatory discharge water treatment.

\section{OBLIGATORY PURIFICATION OF DISCHARGE WATER}

Environmental legislation for agricultural activities is stated in the Activity Decree. After a long preparation process, in July 2017 the final version of the updated Activity Decree was published, including the obligation for greenhouse growers to apply purification for the removal of PPPs when discharging water from the cultivation system (Activiteitenbesluit Milieubeheer, 2018). PPPs (defined as hydrocarbon containing active ingredients) need to be removed from all drain water (discharge from soilless cultivation), drainage water (leakage from soil-bound cultivation) and filter rinsing water (if rinsed with drain water or fertilised irrigation water), independent of cultivation system, crop type or company size. Therefore, this also includes organic farmers, as some PPPs allowed in organic cultivation consist of carbon-based molecules. It is also independent of the destination of the discharged water: directly to surface waters or to the public sewer system. The rationale is that the breakdown of PPPs in the sewage plant is limited, depending on biodegradability of the component (STOWA, 2015), and thus finally also end-up in surface waters. This means that the only way growers do not have to apply purification equipment are either to stop the use of hydrocarbon based PPPs, or completely close the water and nutrient cycle on the company level. This socalled zero-emission cultivation needs to be approved following a stringent protocol (Van Empel and Meis, 2017).

The goal of the obligatory purification of discharge water is reducing the emitted amount of PPPs again to $0.1 \%$ of the applied amount. Calculations with GEM showed that a reduction in PPP emission of 95\% was required to reach this goal. Therefore, the applied purification equipment should remove at least 95\% (weight) of each PPP from discharge water. It is not required to completely mineralise the active ingredients. The national and regional authorities and the growers' organization agreed on an indirect way of establishing the enforcing of the purification efficacy (percentage of removal): growers have to prove they use and maintain an approved purification technology. Technology suppliers can apply for an approval by submitting (independent research) data obtained via a formal test protocol with Standardised Water (see below; van Ruijven et al., 2014), a (realistic worst case) representative of discharge water. The advantage of this approach is that at the growers' locations no analyses of untreated and treated discharged water is required for enforcement and control, saving on money for analyses and comprehensive enforcement efforts. 


\section{APPROVAL PROTOCOL}

A series of steps needs to be followed to realize an approved installation, as shown in Figure 1. The first step in approval is determination of the purification efficacy of the installation, after an optional first technology evaluation. For this purpose, a test protocol was developed and approved by the authorities, in which a standardised method for determination of the purification efficacy was determined. Technology suppliers have to commission an independent research institute to carry out the test according to this protocol. The results of this test along with relevant information about the technology (i.e., implementation at the greenhouse) are reported to and verified by an independent technical committee, consisting of independent experts from public and private organisations. The report includes the applied parameters and constraints for application of the installation, and the purification efficacy for 11 active ingredients from Standardised Water (Figure 1). After approval by the committee, the technology is placed on a publicly available positive list. Only growers applying approved technology in the correct way, that is all their discharged waters are treated, comply with the obligatory purification. When the installation is changed either by the technology supplier or the grower in such a way that the purification efficacy is (potentially) affected, a new approval process needs to be carried out.

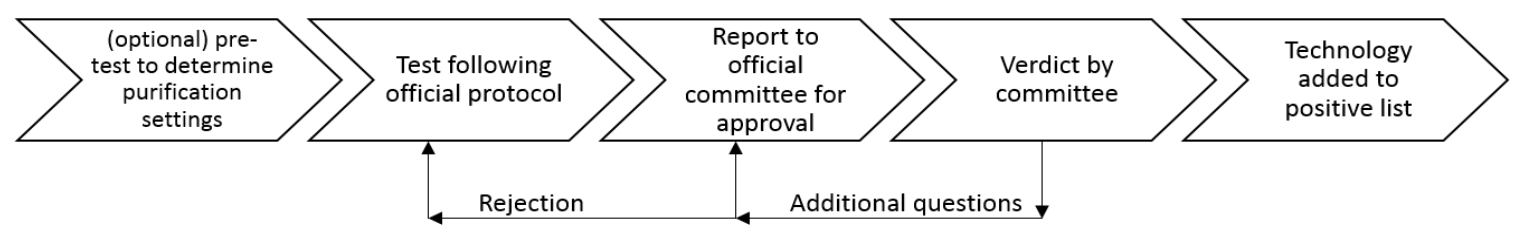

Figure 1. Steps to follow for technology suppliers toward achieving approval for their technology for the removal of PPPs from discharge water.

\section{TEST PROTOCOL}

A formal test protocol was formulated to determine the purification efficacy of water treatment equipment in the removal of PPPs from horticultural discharge water. The protocol enables a statistically sound conclusion on the efficacy in the removal of PPPs. The test protocol is based on the protocols for testing purification equipment developed in previous research (van Ruijven et al., 2014). The development of the protocol was under supervision of the Dutch Ministry of Infrastructure \& Environment and the 'Platform Duurzame Glastuinbouw' (Platform Sustainable Horticulture) (Ministry I\&M, 2017). This platform contains all relevant stakeholders for this case, e.g., water authorities, independent water technology experts, civil servants of the Ministries of Agriculture and Infrastructure \& Environment and sectoral representatives. After approval of the protocol by this platform, the protocol was officially included in the Activity Decree in November 2017.

\section{Statistical basis}

A statistical analysis was performed to decide on the minimal amount needed of samples of untreated and treated water. Total cost for analyses were balanced with certainty on calculated purification efficacy. In order to do so, analytic data of an equipment test were simulated. In the simulation, the number of observations of untreated and treated water $(100$, $50,25,10$ and 5 ) were varied, with a fixed component of $50 \%$ uncertainty of laboratory results (laboratory standard for PPP-analyses). The simulated data were logarithmically transformed, and a linear mixed model (REML) was applied to the transformed data, with date as a block effect, treatment parameters as fixed effects and a linear component for the duration of the experiment, resulting in contrasts between untreated and treated water on a logarithmic scale. These contrasts were retransformed and shown as a reduction compared to untreated water (purification efficacy). The uncertainty distribution of the purification efficacy was calculated by means of a bootstrap with thousand iterations, and shown as an upper and lower limit of the $90 \%$ interval of uncertainty. Table 1 shows the results of the 
simulations. The technical committee concluded that six analyses for untreated and 12 analyses for treated water creates enough certainty about the calculated purification efficacy.

Table 1. Statistical analysis (REML) of amount of samples and in test protocol.

\begin{tabular}{lccccc}
\hline $\begin{array}{l}\text { Number of } \\
\text { observations } \\
\text { untreated water }\end{array}$ & $\begin{array}{c}\text { Number of } \\
\text { observations } \\
\text { treated water }\end{array}$ & $\begin{array}{c}\text { Laboratory } \\
\text { uncertainty } \\
(\%)\end{array}$ & $\begin{array}{c}\text { Estimated } \\
\text { purification } \\
\text { efficacy (\%) }\end{array}$ & $\begin{array}{c}\text { Lower limit } \\
(\%)\end{array}$ & $\begin{array}{c}\text { Upper limit } \\
(\%)\end{array}$ \\
\hline 100 & 100 & 50 & 95.0 & 94.4 & 95.5 \\
50 & 50 & 50 & 95.0 & 94.1 & 95.7 \\
25 & 25 & 50 & 95.0 & 93.8 & 96.0 \\
12 & 24 & 50 & 94.9 & 93.4 & 96.2 \\
10 & 10 & 50 & 94.9 & 93.0 & 96.5 \\
6 & 12 & 50 & 94.8 & 92.5 & 96.6 \\
5 & 5 & 50 & 94.8 & 92.0 & 96.9 \\
3 & 6 & 50 & 94.7 & 91.6 & 97.0 \\
\hline
\end{tabular}

\section{Standardised Water}

To be able to compare the results of multiple tests, it was important to apply test water of a fixed composition in the protocol. Standardised Water (version 1; van Ruijven et al., 2014) was developed for this purpose, being a representative for a realistic worst case composition of greenhouse discharge water from both cultivations in substrate and soil. Therefore it contains macro and micro elements (nutrients), PPPs, organic matter (represented by humic acids, added as leonardite, realizing a constant organic load) and mineral clay (white illite, representing suspended solids).

For the purpose of the official protocol, the composition and physical parameters of Standardised Water Version 1 were critically reviewed and two changes were implemented, as discussed below. 1) In Standardised Water UV-transmittance is a resulting parameter of mainly the presence of humic acids and iron chelates (DTPA). The concentration of both humic acids and iron chelates were considered to be representative, however UV-transmittance was considered to be too low $(<20 \%)$. Therefore, dosage of Leonardite was decreased with $50 \%$ and iron chelate with $25 \%$. This results a UV-transmittance of $25 \%$. 2) The composition for PPPs was changed as well, to create a package of active ingredients more representative for the entire product spectrum. Therefore, azoxystrobin, methiocarb and thiacloprid were replaced by abamectine, esfenvalerate and spinosad. In addition, analysability of the active ingredients was an important factor. Carbendazim was a component of Standardised Water, but could only be added as thiophanate-methyl. This created problems in the calculation of the purification efficacy, as carbendazim was formed by natural and chemical breakdown of thiophanate-methyl and was broken down by the purification equipment at the same time, eventually resulting in a negative purification efficacy. Therefore, it was removed from Standardised Water. Concentrations of the active ingredients were based on the minimal reporting limits from commercially available laboratories. The highest minimal limits from the three best laboratories needed to be $1 \%$ of the concentration in Standardised Water, so that a purification efficacy of $99 \%$ could be analyzed. Table 2 shows the composition of Standardised Water version 2 for nutrients and organic and mineral matter and Table 3 for PPPs after these proposed changes.

Rain water forms the basis for the production of Standardised Water, with well water desalinated with reverse osmosis as an alternative. The water needs to be continuously mixed. After collecting enough water, nutrients are applied in the order as shown in Table 2 . Bicarbonate is used to set the $\mathrm{pH}$ of the solution at 5.5 , sodium chloride finally sets conductivity at $3 \mathrm{mS} \mathrm{cm}^{-1}$. Once the correct $\mathrm{pH}$ is achieved, leonardite and illite are added. PPPs are applied one by one, because the effect of mixing in high concentrations is not wellknown. During the course of the test, the Standardised Water needs to be continuously mixed. 
Table 2. Composition of Standardised Water version 2 for macro- and micro-nutrients, organic and mineral elements and resulting water quality parameters.

\begin{tabular}{lccc}
\hline Macro- and micro-elements & Unit & Target value & Boundary values \\
\hline $\mathrm{NH}_{4}$ & $\mathrm{mmol} \mathrm{L}^{-1}$ & 0.5 & $0.1-0.5$ \\
$\mathrm{~K}$ & $\mathrm{mmol} \mathrm{L}^{-1}$ & 7.0 & $5.0-8.0$ \\
$\mathrm{Ca}$ & $\mathrm{mmol} \mathrm{L}^{-1}$ & 8.0 & $5.0-8.0$ \\
$\mathrm{Mg}$ & $\mathrm{mmol} \mathrm{L}^{-1}$ & 3.5 & $2.5-4.5$ \\
$\mathrm{NO}_{3}$ & $\mathrm{mmol} \mathrm{L}^{-1}$ & 17 & $13-21$ \\
$\mathrm{Cl}$ & $\mathrm{mmol} \mathrm{L}^{-1}$ & 6.0 & $4.0-8.0$ \\
$\mathrm{SO}_{4}$ & $\mathrm{mmol} \mathrm{L}^{-1}$ & 6.0 & $3.5-6.5$ \\
$\mathrm{P}\left(\mathrm{H}_{2} \mathrm{PO}_{4}\right)$ & $\mathrm{mmol} \mathrm{L}^{-1}$ & 0.7 & $0.5-1.5$ \\
$\mathrm{Fe}(\mathrm{DTPA})$ & $\mu \mathrm{mol} \mathrm{L}^{-1}$ & 38 & $30-45$ \\
$\mathrm{Mn}$ & $\mu \mathrm{mol} \mathrm{L}^{-1}$ & 20 & $15-25$ \\
$\mathrm{Zn}$ & $\mu \mathrm{mol} \mathrm{L}^{-1}$ & 5 & $3-10$ \\
$\mathrm{~B}$ & $\mu \mathrm{mol} \mathrm{L}^{-1}$ & 50 & $35-65$ \\
$\mathrm{Cu}$ & $\mu \mathrm{mol} \mathrm{L}^{-1}$ & 2.0 & $0.5-3.5$ \\
$\mathrm{Mo}$ & $\mu \mathrm{mol} \mathrm{L}^{-1}$ & 1.0 & $0.5-1.5$ \\
$\mathrm{HCO}$ & & 1.0 & $0.1-1.0$ \\
$\mathrm{Na}$ & $\mathrm{mmol} \mathrm{L}_{3}$ & 6.0 & $4.0-8.0$ \\
Leonardite & $\mathrm{mmol} \mathrm{L}^{-1}$ & 10 & \\
Illite & $\mathrm{mg} \mathrm{L}^{-1}$ & 6.0 & \\
\hline Resulting parameters & $\mathrm{mg} \mathrm{L}^{-1}$ & & \\
\hline Electrical conductivity & \multicolumn{3}{c}{} \\
$\mathrm{pH}$ & $\mathrm{mS} \mathrm{cm}^{-1}$ & 3.0 & $2.5-3.5$ \\
Temperature & - & 5.5 & $5.0-6.0$ \\
Total organic carbon (TOC) & ${ }^{\circ} \mathrm{C}$ & 20 & $5-30$ \\
UV-transmittance & $\mathrm{mg} \mathrm{L}^{-1}$ & 10 & $7-15$ \\
\hline & $\%$ & 25 & $20-30$ \\
\hline
\end{tabular}

Table 3. Composition of Standardised Water version 2 for PPPs.

\begin{tabular}{lccc}
\hline Active ingredients & Target value $\left(\boldsymbol{\mu} \mathrm{L}^{-1}\right)$ & Boundary values $\left(\boldsymbol{\mu} \mathrm{g} \mathrm{L}^{-1}\right)$ & Commercial product \\
\hline Abamectin & 50 & $25-75$ & Vertimec \\
Boscalid & 10 & $5-15$ & Collis \\
Esfenvalerate & 10 & $50-15$ & Sumicidin \\
Imidacloprid & 4 & $2-6$ & Admire \\
Iprodione & 50 & $25-75$ & Rovral Aquaflo \\
Kresoxim-methyl & 5 & $2.5-7.5$ & Collis \\
Methoxy-fenozide & 10 & $5-15$ & Runner \\
Pirimicarb & 2 & $1-3$ & Pirimor \\
Pymetrozine & 50 & $25-75$ & Plenum 50 WG \\
Spinosad & 10 & $5-15$ & Tracer \\
Tolclofos-methyl & 3 & $1.5-4.5$ & Rizolex \\
\hline
\end{tabular}

\section{Measurements and sampling}

To ensure test conditions, a couple of parameters are measured or analyzed in untreated water as shown in Table 4. A maximum interval of $48 \mathrm{~h}$ may exist between sampling untreated water and start of the test protocol. Sampling of treated water for analyses of PPPs depends on the type of technology used. For inline treatment, treated water needs to be sampled six times in duplo, with a minimum interval of 15 min. For batchwise treatment of the water, six batches of water need to be treated, each to be sampled in duplo. 
Table 4. Measurements and sampling of untreated water in the test protocol.

\begin{tabular}{lcc}
\hline Parameter & Amount & Minimum interval \\
\hline Electrical conductivity & 3 & $10 \mathrm{~min}$ \\
$\mathrm{pH}$ & 3 & $10 \mathrm{~min}$ \\
Temperature & 3 & $10 \mathrm{~min}$ \\
UV-transmittance (if relevant) & 3 & $10 \mathrm{~min}$ \\
Total organic carbon & 1, duplo sample & - \\
Macro and micro nutrients & 1 & - \\
PPPs & 3, duplo sample & $10 \mathrm{~min}$ \\
\hline
\end{tabular}

For some technologies the purification efficacy will reduce in time (for example activated carbon). These technologies require an endurance test to show the productive lifetime for which the required efficacy of $95 \%$ can be achieved. To shorten the run time of these experiments with a factor 10, the concentration of PPPs have to be increased by tenfold, but it should be made plausible that this does not have an effect on the operation of the purification equipment. When using higher concentrations, untreated water can be used for maximum a week after sampling. Every batch of Standardised Water will be analyzed for PPPs (as in Table 3) with in total at least three samples in duplo, for macro- and micro-elements and for total organic carbon. Also measured at least three times are electrical conductivity, $\mathrm{pH}$, water temperature and UV-transmittance (if relevant for the technology). Treated water will be sampled for PPPs at least eight times in duplo. For each sample moment a purification efficacy is calculated. The productive lifetime of the technology is determined by the latest sampling time for which a purification efficacy of at least $95 \%$ for all active ingredients is calculated.

\section{Sample treatment and analysis}

PPPs naturally degrade under influence of temperature and light. Therefore, samples will be stored in glass bottles (dark glass) at $4( \pm 2)^{\circ} \mathrm{C}$. Furthermore, most technologies will apply oxidative reactions for the breakdown of PPPs in water. After sampling, these chemical reactions can continue within the sample container. Therefore, for technologies applying oxidative reactions, $5 \mathrm{~g}$ of sodium sulphite need to be added to each sample of untreated and treated water. Sulphite also needs to be applied to untreated water, to counteract any unknown effect only on treated water.

PPPs need to be analyzed by a laboratory accredited for these analyses. Reporting limits for PPPs will be at maximum 1\% of the concentration in Standardised Water. Analyses need to be performed at latest 7 days after sampling.

\section{Purification equipment}

The purification equipment needs to be tested at a representative capacity $\left(\mathrm{m}^{3} \mathrm{~h}^{-1}\right)$. In this way only one test needs to be executed to achieve an approval for the entire capacity range of the purification equipment of the technology supplier. The required amount of water for execution of the protocol can be calculated from this capacity.

\section{Required purification efficacy}

To receive an approval for the purification equipment, the purification efficacy of all 11 active ingredients in Standardised Water needs to be at least 95\%. The technical committee decided to take the average for each component of 6 samples of untreated and 12 samples of treated water as a benchmark for approval, and not to look at the lower limit of the $90 \%$ interval of uncertainty.

\section{Exception to the required purification efficacy}

During the course of the implementation of the obligatory purification, the application for PPPs containing the active ingredient imidacloprid (e.g., Admire) was restricted. Growers are only allowed to use these PPPs if they can prove to have a zero-emission cultivation 
system, or apply purification equipment with a purification efficacy of at least $99.5 \%$ for this substance. This efficacy could be shown statistically sound with described protocol. Equipment shown capable of removing $99.5 \%$ of imidacloprid in the test get an additional remark on the positive list.

\section{DISCUSSION}

At the end of May 2018, already 13 different installations were approved by the technical committee. Most of the technologies on the list are based on oxidation of PPPs. Oxidation is either done by direct ozonation of molecules through injection of ozone into water, or by an advanced oxidation process, in which hydroxyl radicals are formed in the reaction between UVC-light and hydrogen peroxide, or the combination of hydrogen peroxide and ozone. Another technology applies powdered activated carbon for adsorption of PPPs.

Purification equipment is installed to comply with legislation, return on investment is not to be expected (other than a license to produce). Therefore, some technology suppliers developed additional functionalities that improve the quality of the recirculation water (e.g., disinfection). This dual functionality makes the equipment more attractive, but despite this option, a lot of growers are still hesitative of purchasing an installation, probably waiting for cheaper or better solutions. As enforcement of the legislation is taking off now, expectation is that growers will make a decision soon.

Growers can choose from three options for the application of purification equipment: 1) purchase or lease an installation for application at their own company; 2) apply an installation together with a group of growers; or 3) apply a mobile installation. Application at own company gives the grower the freedom to use equipment with dual functionality, e.g., to not only treat the discharge water, but with the same technology he can also treat recirculation water for disinfection or purification. For growers with small amounts of discharge water throughout the year, or a large amount only once a year, treatment with a mobile installation by a contractor can be financially sound. These companies then only need to invest in sufficient storage and piping. In some greenhouse areas, it can be an interesting option to collect discharge water from a group of companies and treat it collectively at a central location. In the Dutch situation, growers had to choose for this option before 2016, since collective purification needed to be registered by then. After handing in a business-plan before January 1,2017 , government could allow these collectives extension for the obligatory purification, depending on the local situation ultimately to January $1,2021$.

The described method for implementation of purification of discharge water is applicable in other countries as well. Choices as described in this article can be critically reviewed for the local situation. Especially the composition of Standardised Water should be evaluated for the local situation. Furthermore, national or local authorities will decide on the required purification efficacy, but we advise to include all relevant stakeholders in an early stage in the decision process for support and to increase the likelihood of successful adoption and enforcement of the (obligatory) purification.

\section{CONCLUSIONS}

This article describes the implementation of the obligatory discharge water treatment for the removal of PPPs. For the purpose of improving the quality of surface water and keeping PPPs available for use in greenhouse horticulture, the government and the horticultural sector have collaboratively decided on implementation of a method in which the required purification efficacy of 95\% (and 99.5\% for imidacloprid) is guaranteed for all approved technologies. Test protocol is developed by Wageningen University \& Research, Business Unit Greenhouse Horticulture. Technology suppliers have their technologies tested at independent research institutes using an official test protocol and approved by a technical committee. The method is proven to be adequate in testing the purification efficacy of various technologies. Described method for implementation of discharge water treatment is applicable in other countries as well. The composition of Standardised Water should be evaluated for the local situation and national or local authorities should decide on the required purification efficacy and implementation, but preferably with involvement of all relevant stakeholders. 


\section{ACKNOWLEDGEMENTS}

The authors want to thank the Ministry of Infrastructure \& Environment, the TKI T\&U and Stichting Programmafonds Glastuinbouw for funding the research required for the implementation process of the obligatory discharge water treatment.

\section{Literature cited}

Activiteitenbesluit Milieubeheer. (2018). http://wetten.overheid.nl/BWBR0022762/2018-01-01.

Beerling, E.A.M., Blok, C., Van der Maas, A.A., and Van Os, E.A. (2014). Closing the water and nutrient cycles in soilless cultivation systems. Acta Hortic. 1034, 49-55 https://doi.org/10.17660/ActaHortic.2014.1034.4.

Centrum voor Milieuwetenschappen Leiden (CML). (2016). Atlas Bestrijdingsmiddelen in Oppervlaktewater. http://www.bestrijdingsmiddelenatlas.nl.

Groen, E.H. (2015). Emissie als omissie? Onderzoek naar potentiele emissieroutes naar het freatisch grondwater vanuit de substraatteelt. https://www.hhdelfland.nl/over-ons/vergaderoverzicht-bestuur-enstukken/2016_9_13_college-van-dijkgraaf-en-hoogheemraden/4-3/D1272563V2808207.pdf/view/++widget++ form.widgets.file/@@download.

Hoogheemraadschap van Delfland. (2010). Waterkwaliteit glastuinbouwgebied Delfland 2005-2009. http://edepot.wur.nl/164205.

Hoogheemraadschap van Delfland. (2015). Waterkwaliteitsrapportage Delfland 2014. https://www.hhdelfland. nl/actueel/nieuws/copy_of_Waterkwaliteitsrapportage2014def.pdf.

Hoogheemraadschap van Delfland. (2016). Waterkwaliteitsrapportage 2015; Resultaten van een fysisch-chemisch en hydrobiologisch onderzoek. https://www.hhdelfland.nl/actueel/nieuws/DMSP1260044 Waterkwaliteitsrapportage_2015.pdf.

Hoogheemraadschap van Delfland. (2017). Waterkwaliteitsrapportage 2016. https://www.hhdelfland.nl/ waterkwaliteitsrapportage-2016.

Ministry I\&M. (2017). Meetprotocol voor het testen van het zuiveringsrendement van zuiveringsinstallaties glastuinbouw. https://www.helpdeskwater.nl/onderwerpen/emissiebeheer/agrarisch/glastuinbouw/ rendement/@178939/meetprotocol-testen/.

STOWA. (2015). Verwijdering van microverontreinigingen uit effluenten van RWZI's. Rapport 27, 2015. http://watermozaiek.stowa.nl/upload/publicatie2014/STOWA\%202015\%2027\%20Webversie\%20LR\%20Def.p df.

Van der Linden, A.M.A., Hoogsteen, M.J.J., Boesten, J.J.T.I., Van Os, E.A., and Wipfler, E.L. (2017). Fate of Plant Protection Products in Soilless Cultivations after Drip Irrigation: Measured vs. Modelled Concentrations. RIVM report (Bilthoven: National Institute for Public Health and the Environment), p.2016-0063.

Van Empel, D., and Meis, G. (2017). Aanpak aantonen nul-lozing glastuinbouw. https://www. glastuinbouwwaterproof.nl/content/5Zuiveringsplicht/doc/Artikelen/170320_nullozing_werkwijze_def_PDG.PD F.

van Ruijven, J.P.M., Van Os, E.A., Van der Staaij, M., and Beerling, E.A.M. (2014). Evaluation of technologies for purification of greenhouse horticultural discharge water. Acta Hortic. 1034, 133-140 https://doi.org/10.17660/ ActaHortic.2014.1034.15.

Vermeulen, T., Van der Linden, A.M.A., and Van Os, E.A. (2010). Emissions of plant protection products from glasshouses to surface water in The Netherlands. Report GTB-1002. http://library.wur.nl/WebQuery/ wurpubs/fulltext/139929.

WFD. (2000). EU Water Framework Directive 2000/60/EC. http://eur-lex.europa.eu/legal-content/EN/ TXT/?uri=CELEX:32000L0060.

Wipfler, E.L., Vink, C., Ter Horst, M.M.S., and De Jong, A. (2015). Manual GEM 1.1.1: Greenhouse Emission Model, Exposure Assessment Tool for Plant Protection Products Used in Greenhouse Crop Cultivation. Alterra report 2614 (Wageningen: Alterra, Wageningen-UR). 